\title{
“大学の格付けランキング”を超えて
}

\section{The ratings game}

2010 年 3 月 4 日号 Vol. 464 (7-8)

現在ある世界の大学格付けランキングには問題点が多く、それ自体の改善が必要だ。 大学関係者は高順位を狙うべく努力しているが、格付け結果をより賢明に解釈する必要がある。

フランスのニコラス・サルコジ大統領は、 同国の大学が世界ランキングでお粗末な 結果になったことをかなり気にしている らしい。実際、「フランスの大学がベス ト 20 に 2 校、ベスト 100 に 10 校入る こと」を目標に設定するよう研究・高等 教育省に命じた。こうした風潮はサルコ ジ大統領に限らない。今や、ランキング の順位向上をめざす動きが、世界各国の 政策決定や研究資金提供の決定に影響を 与えるようになっている。しかし、大学 の格付けには、それ自体に問題点がある ことはよく知られている。

大学の格付けシステムには多くのもの がある。なかでも最も有名なのが、中 国国内の大学と他の大学を比較するこ とを目的として 2003 年に上海交通大学 が創設した格付けと、英国ロンドンの Times Higher Education という雑誌が 2004 年に商業出版事業として始動させ た格付けだ。これらのランキングでは、 各大学の研究論文発表数、世間の評判な どの重み付け指標を合計して、総合得点 を算出している。

ところが数多くの論者が指摘してきた ように、こうした現行のシステムでは、 研究を偏重する傾向がみられる。そして、 別の形の学問的業績や、学生教育におい て、批判的思考を育み、イノベーション を起こす力をどの程度効果的に身に付け させているか、といった他の重要な要素 が十分には考慮されていない。また、こ れらの格付けシステムでは、論文引用率 の高い生物医学分野で大規模な講座をも つ大学が過大評価され、工学や社会科学 を重視する大学が不利に扱われる傾向も
ある。それに加え、大学が評価対象の単 位としてふさわしいかどうかにも疑問の 余地がある。研究についての評価であれ ば、個々の学部や研究室を評価の単位と したほうが意味があるといってよい。 それでも、格付け上位の大学は、こう した既存のシステム上の重大問題に疑問 を投げかけず、ランキングが上だという 事実を前面に押し出して満足してしまう ことが非常に多い。その結果、格付けの 信頼性が水増しされている。政策当局者 やジャーナリストも、こうした格付けを 額面どおりに受け取ることが多くなって いる。要するにサッカーリーグの格付け ランキングのような見方で、そもそも、 こうしたやり方に意味があるのかどうか 疑わしいのだ。

幸いなことに、次世代の格付けシステ ムが、こうした課題のいくつかに取り組み 始めている (Nature 2010 年 3 月 4 日号 16 ページ参照)。新しい格付けシステム は、より多元的なシステムをめざしている。 大学を比較する際も、総合得点という単 一の数值に従来ほど着目せず、研究、教 育、地域社会や産業界への貢献といった、 具体的な側面をより重視している。また、 例えばハーバード大学のように運営資金 の潤沢な大学と、限られた資金で卓越し た成果をあげている小規模大学を同じ土 俵で比較するのをやめ、類似性のある大 学どうしを比較する方向へと動いている。

そして、これが最も重要かもしれない が、新しい格付けシステムでは、単純な 順位表を並べる形から、それぞれの順位 表を作るもとになったデータベースを公 表する方向へと、舵を切り始めた。こう
した動きは、長い間待たれていたことだ。 その結果、ユーザーは、自分にとって重 要と思われる基準に基づいて、オンライ ンで大学を比較できるようになった。

信頼できる大学情報データベースこそ が、透明性と説明責任のためのツールと して最も重要であることが浮き彫りに なっている。この点で、政府や大学がで きるのは、入手可能なデー夕の質的改善 と量的拡大を進めていくことだ。また、 例えば経済や社会への貢献など、大学の 中核的機能を測定する方法を、さらに改 善する努力を進めていく必要がある。こ れが進めば、欧州委員会が現在行ってい るような独自の格付けシステムの提案を 例に出すまでもなく、さまざまな果実が 得られるであろう。

大学は、格付けによって政策決定が過 剩に影響を受けすぎないよう、十分に注 意を払う必要がある。このようなリスク は、2008 年のイングランド高等教育資金 配分会議の格付けの影響に関する報告書 (http://go.nature.com/Ssi6Rr) で取り上 げられた。好むと好まざるとにかかわら ず、格付けは今後も続く。格付けの乱用 を防止し、格付けの限界について説明し、 大学事業のより全体論的な評価を行うた めの活動を支援することが、大学にとって 最も重要な課題だ。最近、経済協力開発 機構（OECD）が、高等教育は「わずか な数の基準では要約はできない。そうし た基準を用いると、考慮される要素より無 視される要素のほうが多くなる」と指摘し (http://go.nature.com/Lld7d7)、格付け 万能の風潮に強烈な一撃を見舞った。

(翻訳 : 菊川要) 